\title{
Lean Six sigma Integration to Reduce Waste in Tablet coating Production with DMAIC and VSM Approach in Production Lines of Manufacturing Companies
}

\author{
Muhammad Kholil ${ }^{1}{ }^{\text {, Jakfat Haekal }}{ }^{1}$, Adizty Suparno ${ }^{1}$, \\ Dhita Savira Oktaandhini ${ }^{1}$ and Tri Widodo ${ }^{2}$
}

${ }^{1}$ Department of Industrial Engineering, Universitas Mercu Buana, DKI Jakarta, Indonesia

2Universitas Islam Muhammadiyah Tanggerang, DKI Jakarta, Indonesia

*Corresponding author details: Muhammad Kholil; muhammad_kholil@mercubuana.ac.id

\begin{abstract}
PT. Medica Indonesia was founded in 1969 and is one of the most significant ethical pharmaceutical companies in Indonesia. PT. Medica Indonesia, located in Cikarang, has a Pilot Plant Department that acts as a scale-up facility after lab scale to ensure that QTPP (Quality Target Product Profile) is consistently achieved on a pilot scale and a production scale. The high reject rate of $3.6 \%$ of the reject target of $0.5 \%$ for Tablet coating $\mathrm{A}$ products is a threat to the company because it can reduce productivity at PT. Medica Indonesia. Moreover, the Tablet coating A product is a mainstay product. In improving and improving the production line, it is necessary to identify the causes of waste. The integration of Lean Six Sigma using the DMAIC, VSM and VALSAT methods is an effective way to determine waste and the causes of waste. The analysis stage was carried out using the WRM and WAQ tools and determining recommendations for improvement using FMEA.
\end{abstract}

Keywords: lean six sigma; DMAIC; VSM; VALSAT; FMEA

\section{INTRODUCTION}

The challenges of very tough global competition can eliminate businesspeople or companies that are not ready to face this competition. Consumers have been spoiled with various service choices, both in the form of products and services because of this competition. Moreover, finally those who can stay in business and win the competition or competition always try to make improvements oriented to customer satisfaction (Syukron \& Kholil, 2013). The Indonesian pharmaceutical industry certainly cannot isolate itself from this development and competition. The challenges and problems faced by the pharmaceutical industry will become increasingly complex. Competition is not only about how high the productivity level of the company is and how low is the product or service, but also includes the quality of the product or service, comfort, convenience and accuracy and the speed of time in its achievement (Ariani, 2003).

A successful quality strategy begins with an organizational environment that fosters quality development followed by understanding the principles of quality to involve workers in the activities needed to implement quality (Heizer \& Render, 2009). PT. Medica Indonesia is a company that has grown from a small company founded in 1969 to one of the largest ethical pharmaceutical companies in Indonesia in the early 21st century and has become a leading and respected player in the domestic pharmaceutical market.
At PT. Medica Indonesia, located in Cikarang, has a Pilot Plant Department that acts as a scale-up facility after lab scale to ensure that QTPP (Quality Target Product Profile) is consistently achieved on a Pilot Scale and Production scale. The products produced are uncoated and coated tablets, oral liquid, and semi solid. A coating tablet is an anticoagulant drug which functions to inhibit the formation of blood clots. This drug can be used to reduce the risk of strokes and blood clots in people with atrial fibrillation-type heart rhythm disorders and treat people with deep vein thrombosis or pulmonary embolism. In addition to treatment, coating A tablets are also consumed by patients after hip or knee replacement surgery, to prevent blood clots in the legs (deep vein thrombosis) or the blood clots escape into the lungs (pulmonary embolism) (Prom \& Spinler, 2011). The high number of rejects in Tablet coating A products is a threat to the company's sustainability because it can reduce productivity at PT. Medica Indonesia.

Moreover, the Tablet coating A product is a mainstay product. To avoid this, it is necessary to control quality in the production process to determine the factor causing the largest rejects. The number of rejects produced can be reduced. The following is data on the defect of Tablet coating products in 2020 . 
TABLE 1: Total Production and Total Defect of coating Tablet A in 2020

\begin{tabular}{|c|l|c|c|c|}
\hline No & Month & Total Products (g) & Defect (g) & Defect (\%) \\
\hline 1 & January & 20047 & 510 & 2,5 \\
\hline 2 & February & 20947 & 680 & 3,2 \\
\hline 3 & March & 20018 & 675 & 3,4 \\
\hline 4 & April & 20471 & 670 & 3,3 \\
\hline 5 & May & 20601 & 680 & 3,3 \\
\hline 6 & June & 20591 & 679 & 3,3 \\
\hline 7 & July & 20156 & 650 & 3,2 \\
\hline 8 & August & 20221 & 672 & 3,3 \\
\hline 9 & September & 20121 & 720 & 3,6 \\
\hline 10 & October & 20115 & 610 & 3 \\
\hline 11 & November & 20320 & 593 & 2,9 \\
\hline 12 & December & 20070 & 498 & 2,5 \\
\hline
\end{tabular}

Quality control of drugs is important because they relate to the body's systems and are distributed directly through the blood. If there is an error or product contamination, it will directly affect humans, such as death, poisoning, and so on. Therefore, it is necessary to control the quality by analyzing the causes of waste in the Tablet coating A product at PT. Medica Indonesia using the DMAIC method which is integrated with VSM. DMAIC is a methodology used in Six Sigma to solve problems that arise. This methodology aims for continuous improvement of the process to achieve standards and customer desires and satisfaction. Value Stream Mapping is an ideal tool as a first step in carrying out a process improvement in a company that is used to help visualize the overall production process, which represents both the flow of material as well as the flow of information to get lean manufacturing conditions (Goriwondo et al., 2011). This mapping aims to identify all types of waste along the value stream and take steps to eliminate this waste. One of the critical things that must be contained in VSM is the data cycle time. Cycle time states the time it takes for one operator to complete all elements or work activities in making one part before repeating the activity to make the next part. The determination of Cycle Time can be done by measuring time, according to Barnes, R. M. (2009), the time measurement method can be divided into two parts, namely direct time measurement (job sampling and stopwatch) and indirect time measurement (Rahmana \& Almira, 2017).

Failure Modes and Effect Analysis (FMEA) is a methodology in product development and operations management to analyze potential failures in a system classified based on the severity and probability of failure. A failure mode is any error or defect in a process, design or item, especially those that affect the customer. The success of FMEA can assist the team in identifying potential failures based on past experience with similar products or processes. Before starting the analysis with FMEA, it is essential to complete the pre-work to ensure that robustness and past history are included in the analysis (Ambekar et al., 2013).

From the research results of Hidayat et al. (2014) entitled Implementation of Lean Manufacturing with VSM and FMEA Methods to Reduce Waste in Plywood Products (Case Study of PT. Kutai Timber Indonesia Production Dept.) found that there are 3 types of waste after analyzing Value Added Time and Non-Value-Added Time with current state map, namely waste product defects, waiting time, and unnecessary inventory. After the three wastes were identified, recommendations for improvement were made based on the highest RPN value, namely increasing the number of dryer machines from 1 machine to 2 machines, so that it is expected to minimize the waiting time that occurs and minimize the amount of material experiencing WIP. Therefore, to minimize defective products, researchers used the DMAIC method, which is integrated with VSM (Value Stream Mapping) to determine the causes of waste in coating tablets A. By analyzing existing processes with current value stream mapping, it can be seen that wastes. which must be eliminated to increase the effectiveness and efficiency of the process itself. In addition, the FMEA (Failure Mode Effect and Analysis) method is used as a solution to the problem, because this method is relevant to determine the factors that cause the most significant waste products, so that corrective action can be taken to reduce the amount of waste.

\section{RESEARCH METHODOLOGY}

\section{Types of research}

Medica Indonesia, which produces coating tablets A. Quantitative research uses data in the form of numbers as a tool to analyze information about what you want to know. Based on the type of data, this research is referred to as quantitative research. The data obtained by quantitative analysis techniques result from direct observation or interviews with related parties at PT. Using this type of quantitative research is because this study uses numerical data and emphasizes the research process on measuring objective results.

\section{Types of Data and Information}

\section{- Types of Data Used}

The type of data used in the implementation of this research consists of 2 types including:

(1) Quantitative data

Data in the form of numbers or numbers to be imported. This data is obtained from the company in the form of numbers such as production cycle time data.

\section{(2) Qualitative Data}

Data in the form of words, sentences, schemes, and pictures. Qualitative data in this study is data obtained from companies in the form of written or oral information, namely the description of production activities. 


\section{- Data sources}

This research data using sources, namely:

(1) Primary Data

Primary data is data obtained directly from the field by researchers as the research object-primary data obtained from interviews with related parties and direct observation during the production process Primary data in this study are the number of work stations, the flow of the production process, the time of the production process, the waiting time for the production process.

(2) Secondary Data

Secondary data from PT. Medica Indonesia such as production lead time, monthly production results and defect product data. Secondary data is data that does not directly provide information such as documents or literature.

\section{Data Collection Methods}

The data collection method is a way to obtain primary and secondary data for research purposes. In this study, the data collection methods used were as follows:

\section{- Library Research}

This method is in the form of collecting data from several supporting literature that can support any data collection and discussing the object under study.

\section{- Field Study (Field Research)}

(1) Direct Observation (Observation)

This can be done by recording and observing the object of research to collect the required data, such as a description of the production of Tablet coating A to determine defects and factors causing defects in the production process by directly going to the field

(2) Interview

This can be done directly to all competent parties at the company, namely the production team, to get production data to manufacture coating tablets $\mathrm{A}$ and the quality team to find product defects.

\section{- Documentation Study}

Collecting data by studying and observing every source of documents owned by the company that are considered data, such as production data and lead time.

\section{Data Processing and Analysis Methods}

After collecting the data, it will be continued to process the data. The following are the steps carried out by researchers in processing:

\section{- Production System Analysis}

At the analysis stage of the production system in research on the Tablet coating A production line at PT. Medica Indonesia, carried out the following analysis stages:

(1) The production line running on the Tablet coating A production line at PT. Medica Indonesia.

(2) Production processing time at each station.

\section{- Lean Six Sigma Integration DMAIC, VSM, FMEA}

The following are the steps involved in identifying waste in the production of Tablet coating A at PT. Medica Indonesia

A. Define, Measure, Analysis, Improve and Control (DMAIC) DMAIC is a structured problem-solving method, often used for quality and process improvement. DMAIC is an implementation of the Six Sigma philosophy. The DMAIC method consists of five main stages, define, measure, analyze, im-prove, and control.

\section{(1) Define}

This stage is the initial stage in six sigma. At this stage, the targeting and identification of the process and process bottle neck will be carried out. The define waste stage carried out in this research is integrated with the Value Stream Mapping method.

\section{(2) Measure}

What is done in this stage is to calculate the adequacy test and the uniformity of the data used.

\section{(3) Analyze}

At this stage is the stage of analyzing, looking for and finding the root cause of a problem. In this study, the analysis stage was carried out using the VALSAT method and the fishbone diagram. The main function of VALSAT is as a method that helps find the causes of waste in the production process (Hines \& Rich, 1997).

\section{(4) Improve}

At this stage, FMEA (Failure Mode and Effect Analysis) is used to determine priority improvement plans. FMEA is a systematics of activities that identify and evaluate potential failure rates in a system, product or process, especially at the root functions of the product or process on the factors that affect the product or process.

The purpose of FMEA is to develop, increase, and control the probability values of failure detected from the source (input) and also reduce the effects caused by the failure event (Hidayat, 2007). Each type of failure has 1 (one) RPN (Risk Priority Number), which is the result of multiplying the ranking of severity, detection, and occurrence. Then the RPN is sorted from largest to smallest, so that it can be seen the most critical types of failures that are a priority for corrective action (Vanany et al., 2007)

\section{(5) Control}

This stage is the stage for controlling the process that has been repaired. This control can be done by monitoring the daily production output after balancing the production line. This control or control stage serves to ensure that improvements are being made effectively.

\section{B. Value Stream Mapping (VSM)}

Value stream mapping is a map that summarizes or describes the production process starting from the supply of materials, the production process until the product is in the hands of the customer. Therefore, VSM helps in finding waste in the production process. The following is an explanation for making Value Stream Mapping.

(1) Make Current Value Stream Mapping

The current value stream mapping is needed as the basis for making the proposed state map.

(2) Identification of Waste with VSM.

At this stage, the identification of material flow during the production process, activities along the value stream, cycle time of the assembling process, and the need for man power in each activity and other process data are carried out.

(3) Analysis of the Root Cause of Waste.

This analysis was carried out using a fishbone diagram to determine the main root causes of waste. Proposed improvements with Lean Tools, including using a Pareto diagram or a fishbone chart.

(4) Creating a Future State Map

The Future State Map is obtained from the results of reducing waste on the Current State Map. 
However, mapping the future state still refers to the initial mapping or Current State.

C. Failure Mode and Analysis Effect (FMEA)

Determine the proposed improvement using FMEA, namely assessing severity, occurrence, and detection, then entered into the FMEA table. Then the RPN value is calculated and sorted starting from largest to smallest.

\section{RESULT AND DISCUSSION}

Waste Analysis with Integration of DMAIC, VSM, and VALSAT

\section{- Define}

At the define stage, to find the main waste in the production of Tablet Coating A, it is integrated with the Value Stream Mapping (VSM) method by describing the current state mapping. At this stage, potential activities can be identified by identifying Value Added (VA) and Non-Value Added (NVA). Based on data processing VA and NVA, the valueadded value is higher than the non-value added, which indicates that the cycle time in making Tablet Coating A is good.
However, the authors continue to analyze further at the measure stage and analysis with the integration of VALSAT tools to determine whether there are other wastes.

\section{- Measure}

At the measuring stage, the data adequacy and uniformity calculations are performed to determine whether the data is sufficient and uniform. After calculating, it can be seen from Table 4.8 that the processing time data used is sufficient. In addition, for the data uniformity test results, it can be seen in Figures $4.5-4.9$ that the data used are uniform. Therefore, further analysis can be carried out with the VALSAT tools using the Waste Relationship Matrix (WRM) and the Waste Assessment Questionnaire (WAQ).

\section{- Analyze}

The Analyze stage is carried out by processing data from distributing questionnaires to several departments that handle the production process at the Pilot Plant, such as the Production, Quality, PPIC, and Warehouse with officer-level departments. The following is a chart of questionnaire data processing results.

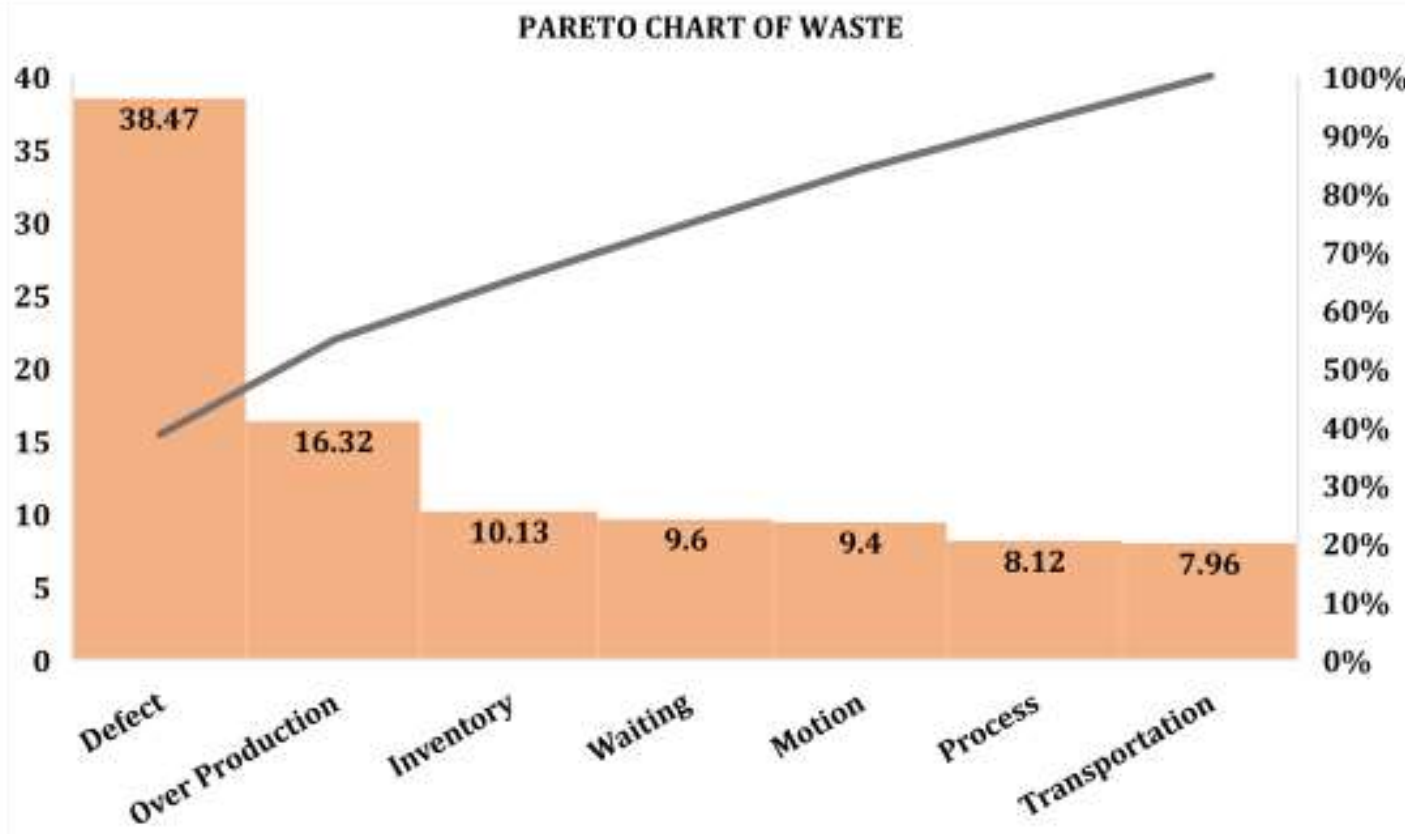

FIGURE 1: Percentage of Waste Rate

Based on the graph above, it is known that the 3 highest waste categories have a big influence in the production process of Tablet Coating A, so that in the next analysis that will be highlighted are the 3 highest waste categories.
Before doing the FMEA analysis, to make it easier to find out the causes of waste, a cause-effect / fishbone diagram was made. The following is the conclusion of all the fishbone diagrams that have been made:

TABLE 2: Conclusion Causes of the Waste from the Fishbone Diagram

\begin{tabular}{|c|c|c|c|c|c|c|c|}
\hline \multirow{2}{*}{ No } & \multirow{2}{*}{ Waste } & \multicolumn{5}{|c|}{ Causes } & \multirow{2}{*}{ Difference } \\
\hline & & Man & Machine & Method & Material & $\begin{array}{c}\text { work } \\
\text { environment }\end{array}$ & \\
\hline \multirow{3}{*}{1} & \multirow{3}{*}{$\begin{array}{c}\text { Defect Tablet } \\
\text { Cracking }\end{array}$} & $\begin{array}{c}\text { Operator } \\
\text { tidak bisa } \\
\text { setting mesin } \\
\text { sesuai spek } \\
\text { tablet } \\
\end{array}$ & \multirow{3}{*}{$\begin{array}{l}\text { The } \\
\text { compressive } \\
\text { force is too } \\
\text { strong }\end{array}$} & \multirow{3}{*}{$\begin{array}{l}\text { Incorrect } \\
\text { way of } \\
\text { handling } \\
\text { granules }\end{array}$} & $\begin{array}{l}\text { Raw material } \\
\text { that contains } \\
\text { high water }\end{array}$ & \multirow{3}{*}{$\mathrm{N} / \mathrm{A}$} & \multirow{3}{*}{$\begin{array}{l}\text { Defect tablet cracking, } \\
\text { namely damage to the } \\
\text { tablet on the edge is more } \\
\text { caused by the operator } \\
\text { incorrectly setting the } \\
\text { machine }\end{array}$} \\
\hline & & \multirow{2}{*}{$\begin{array}{l}\text { Scientist salah } \\
\text { dalam } \\
\text { pembuatan } \\
\text { formula }\end{array}$} & & & $\begin{array}{c}\text { The binder is } \\
\text { not quite } \\
\text { right }\end{array}$ & & \\
\hline & & & & & $\begin{array}{l}\text { Too much or } \\
\text { little } \\
\text { lubrication }\end{array}$ & & \\
\hline
\end{tabular}




\begin{tabular}{|c|c|c|c|c|c|c|c|}
\hline \multirow{2}{*}{ No } & \multirow{2}{*}{ Waste } & \multicolumn{5}{|c|}{ Caueses } & \multirow{2}{*}{ Differencr } \\
\hline & & Man & Mechine & Method & Material & $\begin{array}{c}\text { work } \\
\text { environment }\end{array}$ & \\
\hline \multirow{2}{*}{2} & \multirow{2}{*}{$\begin{array}{l}\text { Defect Tablet } \\
\text { Weight Not in } \\
\text { Accordance } \\
\text { with } \\
\text { Specifications }\end{array}$} & \multirow{2}{*}{$\begin{array}{l}\text { Scientist } \\
\text { salah dalam } \\
\text { pembuatan } \\
\text { formula }\end{array}$} & $\begin{array}{l}\text { Punch that } \\
\text { doesn't lock } \\
\text { well }\end{array}$ & \multirow{2}{*}{$\begin{array}{c}\text { Incorrect } \\
\text { granule pouring } \\
\text { method }\end{array}$} & $\begin{array}{l}\text { Distribution } \\
\text { of different } \\
\text { granule } \\
\text { sizes }\end{array}$ & \multirow{2}{*}{$\mathrm{N} / \mathrm{A}$} & \multirow{2}{*}{$\begin{array}{l}\text { Defect of tablet weight is } \\
\text { not according to } \\
\text { specifications, namely the } \\
\text { active substance contained } \\
\text { in the tablet preparation is } \\
\text { not in accordance with the } \\
\text { specifications, due to poor } \\
\text { granule flow. }\end{array}$} \\
\hline & & & $\begin{array}{l}\text { Improper } \\
\text { mixing } \\
\text { system }\end{array}$ & & $\begin{array}{l}\text { Granule } \\
\text { flow is not } \\
\text { good }\end{array}$ & & \\
\hline 3 & Overproduction & $\begin{array}{l}\text { Salah } \\
\text { perhitungan } \\
\text { untuk } \\
\text { keperluan } \\
\text { uji BE dan } \\
\text { uji stabilita }\end{array}$ & $\mathrm{N} / \mathrm{A}$ & $\begin{array}{l}\text { There is no fixed } \\
\text { (definite) } \\
\text { calculation for } \\
\text { forecasting the } \\
\text { needs of the BE } \\
\text { test and the } \\
\text { stability test }\end{array}$ & $\mathrm{N} / \mathrm{A}$ & $\mathrm{N} / \mathrm{A}$ & $\begin{array}{l}\text { Overproduction, namely the } \\
\text { tablets to be sent for the BE } \\
\text { test and the stability test } \\
\text { are less than those } \\
\text { produced because there is } \\
\text { no definite calculation for } \\
\text { the need for the BE test and } \\
\text { the stability test. }\end{array}$ \\
\hline \multirow[t]{2}{*}{4} & \multirow[t]{2}{*}{ Inventory } & \multirow[t]{2}{*}{ N/A } & \multirow[t]{2}{*}{ N/A } & \multirow{2}{*}{$\begin{array}{l}\text { There is no fixed } \\
\text { (definite) } \\
\text { calculation for } \\
\text { forecasting the } \\
\text { needs of the BE } \\
\text { test and the } \\
\text { stability test }\end{array}$} & \multirow[t]{2}{*}{$\mathrm{N} / \mathrm{A}$} & $\begin{array}{l}\text { Stacking of } \\
\text { finished } \\
\text { products in } \\
\text { warehouses }\end{array}$ & \multirow{2}{*}{$\begin{array}{l}\text { Inventory caused by } \\
\text { overproduction is due to } \\
\text { the absence of a fixed } \\
\text { calculation for the needs of } \\
\text { the BE test and stability test }\end{array}$} \\
\hline & & & & & & $\begin{array}{l}\text { Inadequate } \\
\text { warehouse } \\
\text { conditions }\end{array}$ & \\
\hline
\end{tabular}

From the table above, the orange column indicates the most important cause of waste, namely cracking tablet defect caused by wrong machine settings, tablet weight defect that is not in accordance with specifications caused by poor granule flow during the mixing process overproduction due to the fact that the tablets to be sent for the BE test and the stability test are less than those produced due to the absence of a definite calculation for the needs of the BE test and the stability test, and inventory due to overproduction.

After that, it is continued with an analysis using FMEA to determine improvement activities based on the RPN value with the aim of knowing recommendations for improvements based on the greatest priority. Following are the results of the FMEA analysis of the 3 selected waste categories

TABLE 3: Analysis of FMEA Types of Waste in Tablet Coating Production A.

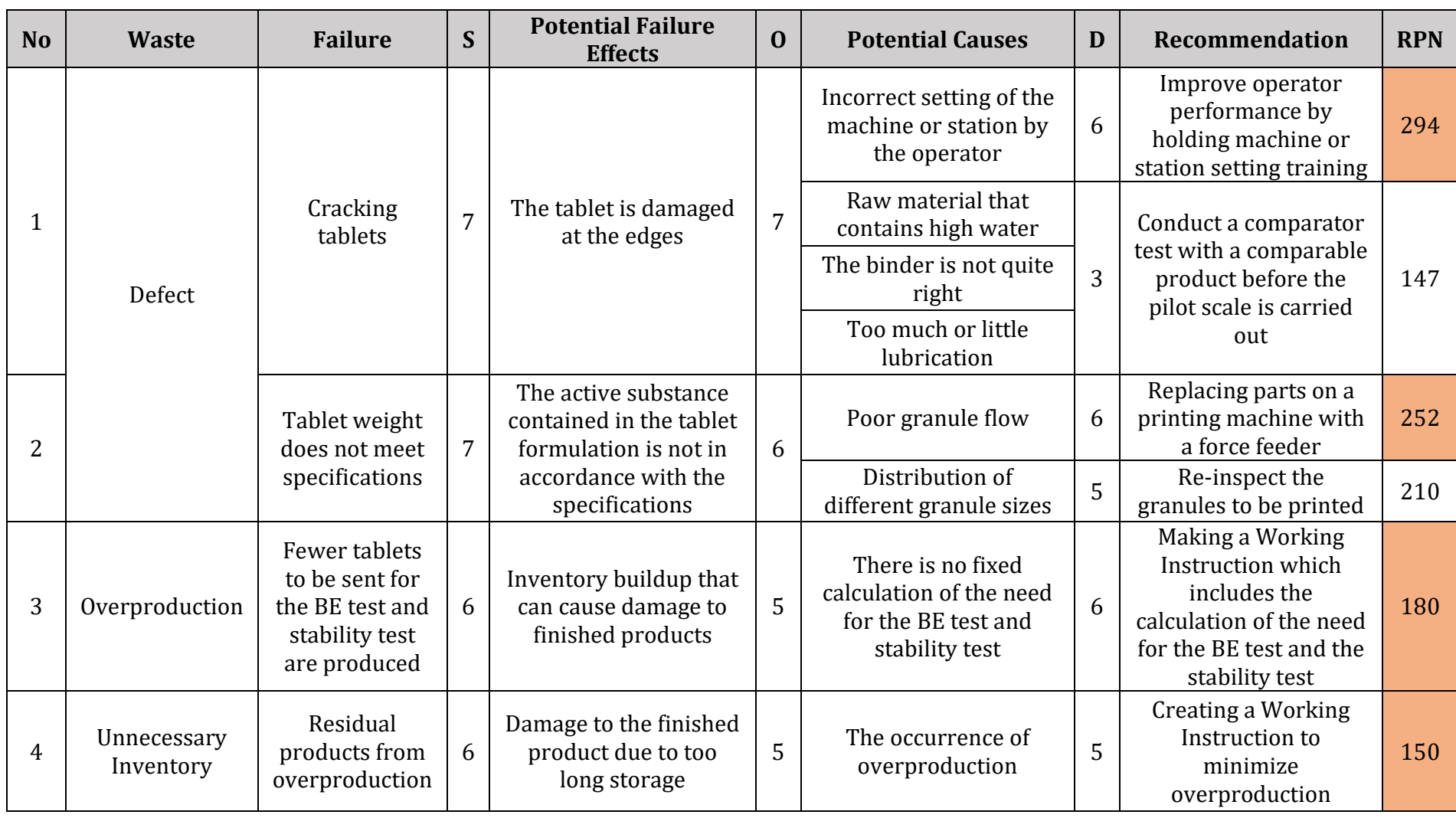


The determination of severity, occurrence and detection values is based on the author's analysis and brainstorming with several related departments. Based on the results of the RPN in the table above, it is known that the highest order of RPN is the cracking tablet defect which causes the highest waste of 294 with a potential failure effect in the form of a broken tablet on the edge, followed by a defect weight of the tablet that does not match the amount of RPN of 252 with a potential failure effect. in the form of tablet weight that becomes non-uniform, RPN overproduction of 180 which causes accumulation of inventory which can cause damage to finished products and RPN unnecessary inventory due to overproduction of 150 .

\section{- Improvement}

The repair activities recommended on FMEA tools have a big influence in minimizing the waste that occurs. The following are activities for proposed improvements.

TABLE 4: Proposed Waste Improvement

\begin{tabular}{|c|c|c|c|}
\hline No & Type of Waste & The main cause & Proposed Improvement \\
\hline $1 \mathrm{~A}$. & Defect cracking tablets & $\begin{array}{c}\text { Incorrect setting of the machine or } \\
\text { station by the operator }\end{array}$ & $\begin{array}{c}\text { Improve operator performance by } \\
\text { holding machine or station setting } \\
\text { training }\end{array}$ \\
\hline $1 \mathrm{~B}$. & $\begin{array}{c}\text { Defect of tablet weight } \\
\text { not according to } \\
\text { specifications }\end{array}$ & Poor granule flow & $\begin{array}{c}\text { Replacing parts on a printing } \\
\text { machine with a force feeder }\end{array}$ \\
\hline 2 & Overproduction & $\begin{array}{c}\text { A coating tablet product that will } \\
\text { be sent for the BE test and } \\
\text { stability test is less in number } \\
\text { than the production results. }\end{array}$ & $\begin{array}{c}\text { Making a Working Instruction } \\
\text { which includes the calculation of } \\
\text { the need for the BE test and the } \\
\text { stability test }\end{array}$ \\
\hline 3 & Inventory & $\begin{array}{c}\text { Residual products from } \\
\text { overproduction }\end{array}$ & $\begin{array}{c}\text { Creating a Working Instruction to } \\
\text { minimize overproduction }\end{array}$ \\
\hline
\end{tabular}

A. Providing Training for Operators

The provision of this training is carried out by the Quality section in collaboration with HR to compile a training syllabus for the operator level.
The preparation of a syllabus or training material is related to cases during work (case studies). Evidence that the operator conducts training can be recorded from the training card as below:

\begin{tabular}{|c|c|c|c|c|c|c|}
\hline \multicolumn{7}{|c|}{ HPLC MODULE DELIYERY CARD } \\
\hline \multicolumn{7}{|c|}{ "HPLC - High Performance through Leaming Culture" } \\
\hline \multicolumn{7}{|c|}{ Research \& Development - PT Medica Indonesia } \\
\hline \multicolumn{7}{|c|}{ Analyst/Staff/Operator, Formulation Development } \\
\hline \multicolumn{5}{|c|}{ Basic Training } & & \\
\hline No & Topic & Subject Matter & Soore & Competenay & Trainirg Date & Trainer \\
\hline 1 & $\begin{array}{l}\text { Orientation to } 0 \text { rganization Structure } \& \text {. } \\
\text { Working Pracess }\end{array}$ & $\begin{array}{l}\text { Intraductian to } 0 \text { rganizatian Structure (STO) and } \\
\text { Jab Des cripti an } \\
\text { Intraduction to Business Pracers }\end{array}$ & 10 & RND System \& Pracedure & & \\
\hline 2 & $\begin{array}{l}\text { Orientati an to } 0 \text { rganization Rale } 2 \\
\text { Strategy }\end{array}$ & $\begin{array}{l}\text { Pharma Bus ines } s \text { \& Devel opment } \\
\text { DXG Strategy \& Rale of R\&D }\end{array}$ & 10 & Bus ines s Awareness & & \\
\hline 3 & $\begin{array}{l}\text { Intraduction to Gaod Manufacturing } \\
\text { Practice }\end{array}$ & Bas ic Principles of Goud Manufacturing Practice & 10 & Gaod Practices & & \\
\hline 4 & Pharmaceutical Praducts Dos age & $\begin{array}{l}\text { Dos age Form and Pharmaceutical Packagi ng } \\
\text { accordi ng to Dos age Form }\end{array}$ & 10 & Farmulatian Devel apment & & \\
\hline 5 & Farmulation Ins trumentati an 0 perati anal & \begin{tabular}{|l|} 
Farmulation Labaratary Ins trumentati an Handling \\
Formulation Labaratary Ins trumentati an \\
Techni cal Unders tanding \\
Das and Dan't an Farmulation Labaratary
\end{tabular} & 10 & Laboratary Ins trumentation & & \\
\hline
\end{tabular}

FIGURE 2: Example of Operator Level Training Card

B. Printing Machine Part Replacement

The part of the printing machine that was replaced was the hopper part. Hopper is a place for storing granules and which flows the granules to be pressed / printed. Initially, after finding that the granule flow constraint is not good, a hopper is made with the help of a propeller (blade) and the help of a force feeder. The purpose of changing this hopper type is to help granules that have poor flow, such as coating tablets A.

C. Making Production Process Working Instruction Making WI of the production process to avoid overproduction. WI will write rules related to BE calculation and stability test required in the production of Tablet Coating A. WI is still a review by the relevant department.
The hope is that with the creation of the WI, the need for tablets for BE tests and stability tests will be known earlier, thus helping the project management team in determining the production capacity each month so that there is no more waste inventory.

\section{- Control}

The final stage of DMAIC is to monitor all repair activities and make it a new standard. In this research, to monitor all repair activities is by making SOPs and conducting routine inspections so that the waste is not repeated. 


\section{CONCLUSION}

Based on observations on waste reduction research on the Tablet Coating A production line at PT. Medica Indonesia, the following conclusions were drawn:

(1) Based on the results of integrating lean six sigma with DMAIC, VSM, and VALSAT tools, it can be seen the types of waste that occur in the Tablet Coating A production line, namely defects, overproduction, and inventory.

(2) Based on the results of the fishbone diagram analysis, it is found that the first cause of waste is a cracking tablet defect caused by an incorrect setting of the machine or station by the operator. In addition, there is a defect in the weight of the tablets not according to specifications caused by poor granule flow. The second waste is overprocessing caused by the tablets to be sent for the BE test and for the stability test to be less than those produced because there is no actual calculation for the needs of the BE test and the stability test. The third waste is inventory caused by overproduction.

(3) Efforts are made to minimize waste that occurs in the production line of Tablet Coating A PT. Medica Indonesia is as follows:

a) To minimize waste in the form of cracking defect tablets, a proposal is made to apply FMEA with priority repairs carried out in the order of the failure-causing factors that have the highest RPN value first, namely by providing training for operators to minimize cracking tablet defects and replacing printing machine parts to minimize defect weight. The tablet does not meet specifications. The defect ratio results obtained have decreased, namely from before the repair, the total defect ratio was $10.35 \%$ to $1.65 \%$.

b) To minimize waste of overproduction and inventory, a suggestion is made to apply the priority improvement of the FMEA, namely by determining the need for BE tests, stability tests, and retained samples which are then written into a working instruction so that production capacity can be optimally planned every month. The results obtained were reduced overproduction and inventory rates in January - March 2020 due to the distribution of samples for the needs of the BE test, the stability test until the retained sample had been determined.

\section{SUGGESTIONS}

Based on the results of the analysis that has been carried out, the researcher provides suggestions as input and material for consideration as follows:

(1) The company carries out the proposed improvements that have been given in this study on an ongoing basis (continuous improvement) to minimize waste that occurs at PT. Medica Indonesia.

(2) For further research, eliminating waste that has not been carried out in this study can be carried out.

\section{REFERENCES}

[1] Adams, G. (1998). The lean enterprise: Designing and managing strategic processes for customer-winning performance. Quality Progress, 31(8), 150.

[2] Adrianto, W., \& Kholil, M. (2016). Analisis Penerapan Lean Production Process untuk Mengurangi Lead Time Process Perawatan Engine (Studi Kasus PT.GMF AEROASIA). Jurnal Optimasi Sistem Industri. https://doi.org/10.25077/josi.v14.n2.p299-309.2015
[3] Ambekar, S., Edlabadkar, A., \& Shrouty, V. (2013). A Review: Implementation of Failure Mode and Effect Analysis. Ijeit.Com, 2(8), 37-41. http://ijeit.com/vol 2/Issue 8/IJEIT1412201302_07.pdf

[4] Aryanto, A. T., \& Auliandri, T. A. (2015). Analisis Kecacatan Produk Fillet Skin On Red Mullet Dengan The Basic Seven Tools of Quality Dan Usulan Perbaikannya Menggunakan Metode FMEA (Failure Modes And Effect Analysis) Pada PT. Holi Mina Jaya. Jurnal Manajemen Dan Terapan, 1(1), 9-23.

[5] Dewanti, D., \& Pujotomo, D. (n.d.). Dina Firma Dewanti, Darminto Pujotomo_) - PDF Download Gratis.pdf (p. 7). Program Teknik Industri, Fakultas Teknik, Universitas Diponegoro.

[6] Dewiyani, L., Rani, A. M., \& Wijaya, D. A. (2020). Upaya Untuk Menurunkan Defect pada Kemasan Sachet Minuman Berenergi dengan Metode Six Sigma di PT BTJ.

[7] Haekal, J., Hanum, B., \& Adi Prasetio, D. E. 2020. Analysis of Operator Body Posture Packaging Using Rapid Entire Body Assessment (REBA) Method: A Case Study of Pharmaceutical Company in Bogor, Indonesia. International Journal of Engineering Research and Advanced Technology - IJERAT (ISSN: 2454-6135), 6(7), 27-36.

[8] Hanum, B., Haekal, J., \& Adi Prasetio, D. E. 2020. The Analysis of Implementation of Enterprise Resource Planning in the Warehouse Division of Trading and Service Companies, Indonesia. International Journal of Engineering Research and Advanced Technology IJERAT (ISSN: 2454-6135), 6(7), 37-50.

[9] Kholil, M., Haekal, J., Eko Adi Prasetio, D., \& Sulaiman Hasan. 2020. The Lean Manufacturing Design for Improving Production Scheduling Using Product Wheel Method in Chemical Manufacturing Company, Indonesia. International Journal of Engineering Research and Advanced Technology - IJERAT (ISSN: 2454-6135), 6(8), 12-18.

[10] Haekal, J., \& Setio, H. 2017. Selection of Raw Material Suppliers Using Analytical Hierarchy Process in Food and Beverage Company, South Jakarta. ComTech: Computer, Mathematics and Engineering Applications, 8(2), 63-68.

[11] HAEKAL, J. (2018). PERANCANGAN DAN EVALUASI IMPLEMENTASI SISTEM MANAJEMEN MUTU ISO 9001: 2015 MELALUI KEPUASAN PELANGGAN DI UNIVERSITAS ISLAM AS-SYAFI'IYAH (Doctoral dissertation, Universitas Mercu Buana Jakarta).

[12] Kholil, M., Haekal, J. H, Sulaiman. 2020. Lean Manufacturing Design to Reduce Waste in Gear Production Process Using VSM and Kaizen Method Approaches (Case Study: Gear Primary Driven K56 Product). Journal of Scientific and Engineering Research. 7(8), 1-9

[13] Haekal, J., \& Prasetio, D. E. A. Planning of Production Facilities Layouts in Home Industry with The Systematic Layout Planning Method.

[14] haekal, J., \& Setiawan, I. (2020). Comparative Analysis of Raw Materials Control Using JIT and EOQ method For Cost Efficiency of Raw Material Supply in Automotive Components Company Bekasi, Indonesia. International Journal of Engineering Research and Advanced Technology (ijerat), 6(10), 76-82. https://doi.org/10.31695/IJERAT.2020.3661 
[15] Haekal, J., Hanum, B., \& Adi Prasetio, D. E. 2020 Application of Quantitative Strategic Planning Matrix (QSPM) For Determination of Alternative Strategies in Food and Beverage SMES in Bogor Indonesia. Journal of Scientific and Engineering Research. 7(7), 137-145

[16] Hanum, B., Haekal, J., \& Adi Prasetio, D. E. 2020. SPHC Material Inventory Control Analysis in Project VL01 Centralized by the EOQ Method in Automotive Company Indonesia. Journal of Scientific and Engineering Research. 7(7), 130-136

[17] Doshi, J., \& Desai, D. (2017). Application of failure mode \& effect analysis (FMEA) for continuous quality improvement - multiple case studies in automobile SMEs. International Journal for Quality Research, 11(2), 345-360. https://doi.org/10.18421/IJQR11.02-07
[18] DW Ariani. (2003). Manajemen Kualitas Pendekatan Sisi Kualitatif. Ghalia Indonesia.

[19] Gasperz, V., \& Fontana, A. (2011). Lean Six Sigma for Manufacturing and Service Industries. Vinchristo Publication, Bogor. Vinchristo Publication.

[20] Goriwondo, W. M., Mhlanga, S., \& Marecha, A. (2011). Use of the Value Stream Mapping Tool for Waste Reduction in Manufacturing.Case Study for Bread Manufacturing in Zimbabwe. International Conference on Industrial Engineering and Operations Management Kuala Lumpur, Malaysia. 